\title{
Implementation of Performance Management on Bank Syariah Mandiri
}

\author{
Amiral Emeraldo Zahari \\ Doctoral Student in Human Resource Management, State University of Jakarta, Indonesia \\ E-mail: amiralemeraldoz@gmail.com
}

Hady Efendy (Corresponding Author)

Education Practice and Academic Consultant

E-mail: efendy_hady@yahoo.co.id

Received: August 23, 2017

doi:10.5296/jmr.v9i4.11846
Accepted: Sep. 29, $2017 \quad$ Published: October 1, 2017

URL: https://doi.org/10.5296/jmr.v9i4.11846

\begin{abstract}
The success of an organization in achieving its vision and mission depends on the quality of its human resources. Organizational management is essentially a process of human resource management because all organizations must operate through human resources. The quality of human resources is reflected in its performance within the company. Employee performance as a human resource is measured in a formal system called performance appraisal. Performance management is applied to achieve the company's vision and mission through employee competence and performance that match the values contained within the company. The targets of each work unit based on the balance scorecard set by the Directorate. The performance of Bank Syariah Mandiri (BSM) employees is monitored through key performance indicator. Performance appraisal of BSM employees is done periodically every 3 months, i.e. quarterly review and annual review. The grouping of employee performance through Performance Level (PL) is used as the basis for reward / appreciation from company to employee. Employee PL determination is aligned with the achievement level of the Work Unit and the composition should approach the normal distribution curve form using the PL predicate. Performance appraisal is self through self-assessment and direct superior through interview based on evidence of employee performance activity (self-assessment result). Implementation of performance management in BSM is good so that the company
\end{abstract}




\section{Macrothink}

Journal of Management Research

ISSN 1941-899X

2017, Vol. 9, No. 4

performance more structured and organized, effective and efficient and encourage employees to work according to procedures, spirit and productive so that the work is more optimal and contribute positively to the company.

Keywords: Performance management, SMART criteria, self-assessment, balance scorecard, engagement 


\section{Introduction}

The success of an organization in achieving its vision and mission is highly dependent on the quality of its human resources (Ambarwati, 2002). Therefore, every organization, large and small must be able to manage its human resources well as well as other elements within the organization. Organizational management is essentially a process of human resource management because all organizations must operate through human resources.

The quality of human resources is reflected in its performance within the company. Employee performance as a human resource is measured in a formal system called performance appraisal. Mondy \& Noe (2005) define performance appraisals as a formal process for assessing and evaluating a person's or group's performance. The importance of employee performance issues makes the writer interested to find out how the company in managing the performance of their employees (performance management).

Performance management is a new concept in human resource management (Esu, 2009). Unlike performance appraisals, performance management is a large and comprehensive system for identifying, encouraging, measuring, evaluating, improving performance, and rewarding employee performance (Mathis \& Jackson, 2006). Armstrong (2009) in Marwansyah (2010) argues that performance management is a systematic process to improve organizational performance by developing individual and team performance.

PT. Bank Syariah Mandiri (BSM) was chosen as the object of research because human resource development is one of the main focus of management at BSM. According to BSM's Annual Report 2016 management report, BSM has a vision to be a Leading and Modern Syariah Bank by providing the best service to customers throughout Indonesia and to be able to face the challenges of a competitive business environment.

During the existence of BSM in Indonesia, BSM has organized various trainings and developed human resources as a form of performance management to ensure that the company's business capabilities continue to meet market demands, and employees are able to produce what is expected of them. Meanwhile, BSM is also continuously recruiting young people with potential to occupy important positions in the future. BSM has a dedicated team dedicated to improving the skills of technical functions, management and employee leadership. The team is supported and certified by a number of training and human resource development institutions. BSM presents a group of facilitators both within the organization itself, as well as from outside environments that have keen business skills, direct work experience in related fields. Based on the above exposure it is very interesting to give further description of "Performance Management at PT. Bank Syariah Mandiri", which includes elements of performance management, such as directing/planning, managing/supporting, review/appraising and developing/rewarding.

\subsection{Formulation of the problem}

The issues to be discussed in this paper are:

1. What is the implementation of performance management in PT Bank Syariah Mandiri?

2. Is the implementation of performance management in PT Bank Syariah Mandiri as 
appropriate?

3. Are there any advantages or disadvantages of the implementation of performance management in PT Bank Syariah Mandiri?

\subsection{The purpose of this paper are:}

1. Knowing the implementation of performance management in PT Bank Syariah Mandiri.

2. Knowing the implementation of performance management in PT Bank Syariah Mandiri has with or should not.

3. Knowing the advantages or disadvantages of implementation of performance management in PT Bank Syariah Mandiri.

\section{Literature Review}

\subsection{Definition of Performance Management}

Wirawan (2009) defines performance as an output generated by functions or indicators of a job or a profession within a certain time. According to Rivai \& Basri (2004) performance is the result of a person as a whole during a certain period in carrying out tasks, such as standards of work, targets or targets or criteria that have been determined in advance and have been mutually agreed.

According Mangkunegara (2000) performance is the result of work in quality and quantity achieved by an employee in performing their duties in accordance with the responsibilities given to him. Hasibuan (2001) argued that performance is a result of work achieved by a person in carrying out tasks assigned to him based on skills, experience and sincerity and time.

From some understanding of performance above it can be concluded that the performance is a result of work achieved by a person in carrying out tasks or work, in accordance with the standard criteria established in the job. To achieve good organizational performance, performance management needs to be laid out through a good performance management system. Dessler \& Huat (2009) argue that performance management is a process that consolidates goal setting, performance appraisal, and employee development into a single system whose goal is to ensure that employee performance supports company performance.

According to Aguinis (2009) performance management is a continuous process of identification, measurement, and development of individual performance that is aligned with the organization's strategic objectives. Armstrong \& Baron (1998) define performance management as a strategic and integrated approach to provide sustainable success for the organization by improving the performance of the employees working within it by developing team capabilities and individual contributions.

Based on these definitions, it is clear that performance management is different from just a performance appraisal. Performance appraisal is only an annual or semiannual event, but performance management is an ongoing process in defining and rating performance, as well as feedback in order to develop employee performance in accordance with the organization's strategic goals. 


\subsection{Performance Management Stages}

Stages of Performance Management According to Williams (1998), there are four major stages in the implementation of performance management. This stage becomes a performance management cycle that is interconnected and supports one another.

1. The first stage: directing / planning. The first stage is the stage of identification of work behavior and basic / performance measurement basis. Then, a concrete briefing on the work behavior and planning of the targets to be achieved, when it is achieved, and the assistance that will be needed. Target indicators are also defined at this stage. Effective targets are specified, measurable, achievable, results-oriented and within certain time limits expressed by the SMART Acronym (Wibowo, 2016) meaning the following:

a. Specific, simple: the meaning is clearly stated, concise and easy to understand.

b. Measurable means can be measured and quantified

c. Attainable, achievable means to be challenging, but still affordable.

d. Result oriented, relevant means focus on results to be achieved.

e. Time-bound, timely, timeliness means there is a time limit, can be traced and can be monitored progress against the target to be corrected.

2. The second stage: managing / supporting. The second stage is the implementation of monitoring on organizational processes. This stage focuses on manage, support, and control over the course of the process to stay on track. The path is meant here is the criteria and work processes in accordance with procedures applicable within an organization.

3. Third stage: review / appraising. The third stage includes the evaluation step. Evaluation done with flashback / performance review that has been implemented. After that, performance is assessed / appraised. This stage requires documentation / record data relating to the object being evaluated. Evaluators must be objective and neutral in order to obtain valid evaluation results.

4. The fourth stage: developing / rewarding. The fourth stage focuses on development and appreciation. Evaluation results become the decision-making guideline for the next action. Decisions can be remedial measures, reward / punishment, continuing an existing activity / procedure, and budgeting.

\subsection{Application Performance Management}

\subsubsection{Performance Management Cycle}

Bank Business Plan is a guideline for every Unit and employees to translate the vision and mission in the implementation of company operations, it is necessary to formulate a comprehensive employee performance appraisal mechanism to ensure and measure the contribution of employees in achieving the objectives of the Bank with the following objectives:

1. Supporting the achievement of organizational goals through the achievement of employee performance.

2. develop a positive corporate culture and oriented to the achievement of performance. 


\section{Macrothink}

3. Increase employee engagement.

The performance management cycle of employees is done through:

1. Management of employee performance is done through the communication process between employees with superiors to achieve common understanding about goals, ways and methods of measuring the achievement of targets.

2. The communication process is carried out periodically and structured over a one-year cycle. The employee performance management cycle occurs in 3 (three) stages as follows:

a. Planning: is a performance planning process undertaken at the beginning of the working period where employees and superiors:

1. Plan what to do for 1 (one) year ahead.

2. Determine how performance should be measured.

3. Obtaining collective agreement on the work concerned.

b. Progress Review: a continuous performance communication process between employees and superiors to share information on:

1. The development of work.

2. Barriers / problems that occur.

3. Solutions to overcome various obstacles.

4. Follow up on individual development that has been planned.

c. The year end review is conducted through:

1. Compare the results achieved with the job goals that have been set.

2. Obtained a collective agreement on performance assessment results.

\subsubsection{Performance Planning}

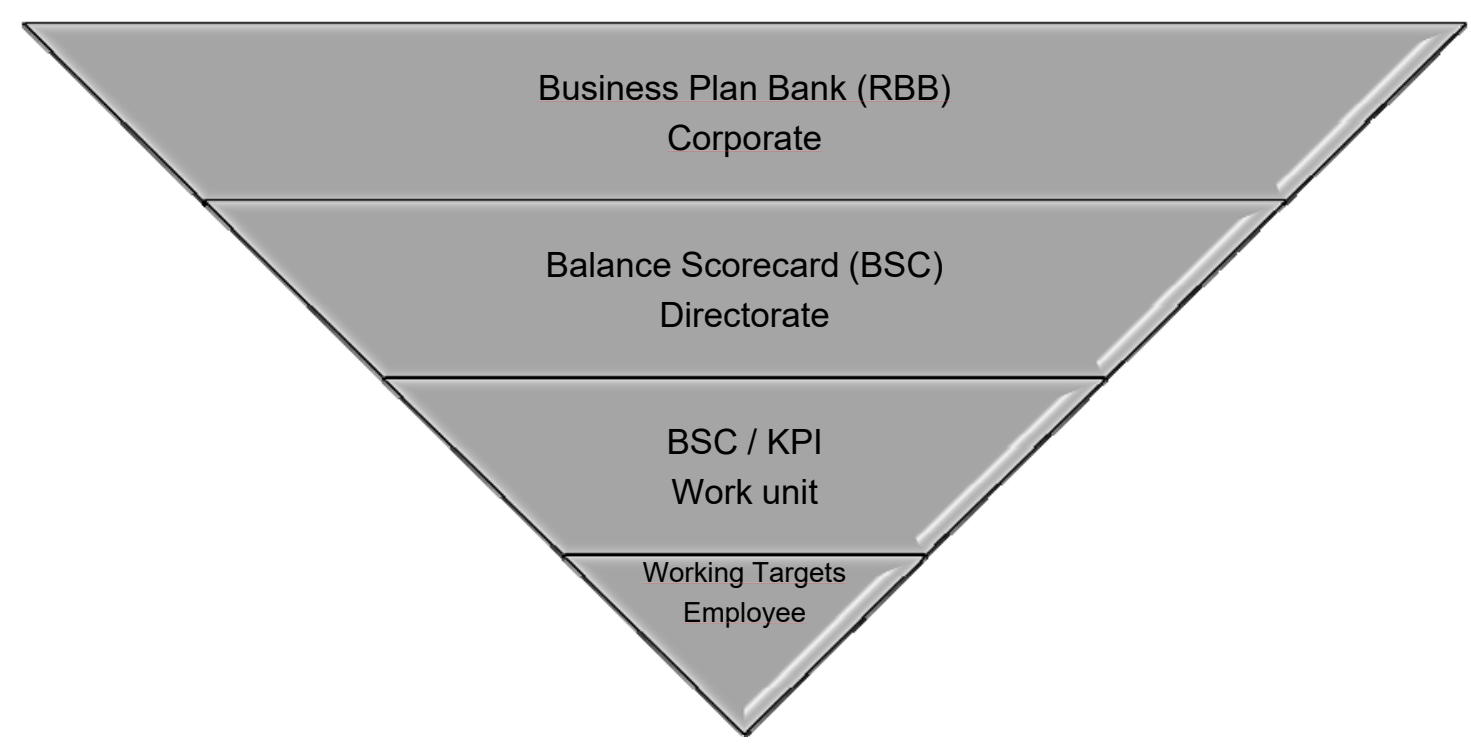

Figure 1. Diagram of Performance Planning System 
1. Performance planning system is integrative between Corporate, Directorate, Work Unit and Individual with the following stages:

- Phase One: The Bank prepares the overall work target set out in the Bank Business Plan (RBB) approved by the Board of Directors/shareholders.

- Second Stage: The Directorate develops the overall objectives before establishing the BSC of each Work Unit based on the RBB in the form of BSC (Balance Scorecard).

- Third Stage: The Work Unit sets the goals of each Work Unit in the form of BSC (Balance Scorecard) The target of the Work Unit is directly targeted by the Head of Work Unit in the form of BSC of all Work Units.

- Fourth Phase: The Work Unit sets up a job target for each employee based on their respective Work Unit objectives. The targets are cascaded by the Head of Work Unit to each employee referring to the strategic objectives based on the BSC (KPI) and routine targets based on job description.

2. KPI's cascading process by the Work Unit to employees under its coordination, superiors must be convinced that the KPI must be in line with the targets of its work units and divided accordingly to the potential / capability of the employees concerned. In addition it must be believed to be cumulative to provide the highest added value for the Bank and beyond the development of industry in general.

3. The Performance Indicators specified must meet the SMART criteria.

Table 1. SMART

\begin{tabular}{|l|l|}
\hline \multicolumn{1}{|c|}{ Criteria } & \multicolumn{1}{c|}{ Explanation } \\
\hline Specific & Specifies what will be achieved \\
\hline Measurable & Achievable results can be measured \\
\hline Achievable & The performance plan must be challenging but still achievable \\
\hline Realistic & Targets are based on real conditions \\
\hline Time-bound & Has a timeout for completion \\
\hline
\end{tabular}

4. Each work target has a weight assigned jointly between superiors and subordinates in accordance with work priority with total weight equal to $100 \%$. Determination of weight is done on each work target based on importance level and then converted in percentage form.

5. Each work objective must be accompanied by a Key Performance Indicator tailored to the specified work objectives. The preparation of performance indicators is needed to measure the success of the achievement of the work objectives and is the basis for the performance appraisal of employees.

\subsubsection{Performance Assessment}

1. Assessment of the achievement of the work done by comparing the target with the realization of the achievement of targets. Assessment is interactive and open in which each 


\section{Macrothink}

Journal of Management Research

ISSN 1941-899X

2017, Vol. 9, No. 4

employer discuss with the employee about developments and constraints encountered in the implementation of work.

2. Performance appraisal adheres to the main principle of goal-oriented orientation and encourages employees to further develop their ability to work. Head of Work Unit and supervisors are responsible for providing direct guidance and motivation in the form of coaching, counseling and feed back to subordinates in order to work better and avoid failure of achievement of targets at the end of the year.

3. The process undertaken in the performance appraisal stage is as follows:

a. Progress Review

Performed periodically every 3 (months). Progress Review performance is done formally by all employees.

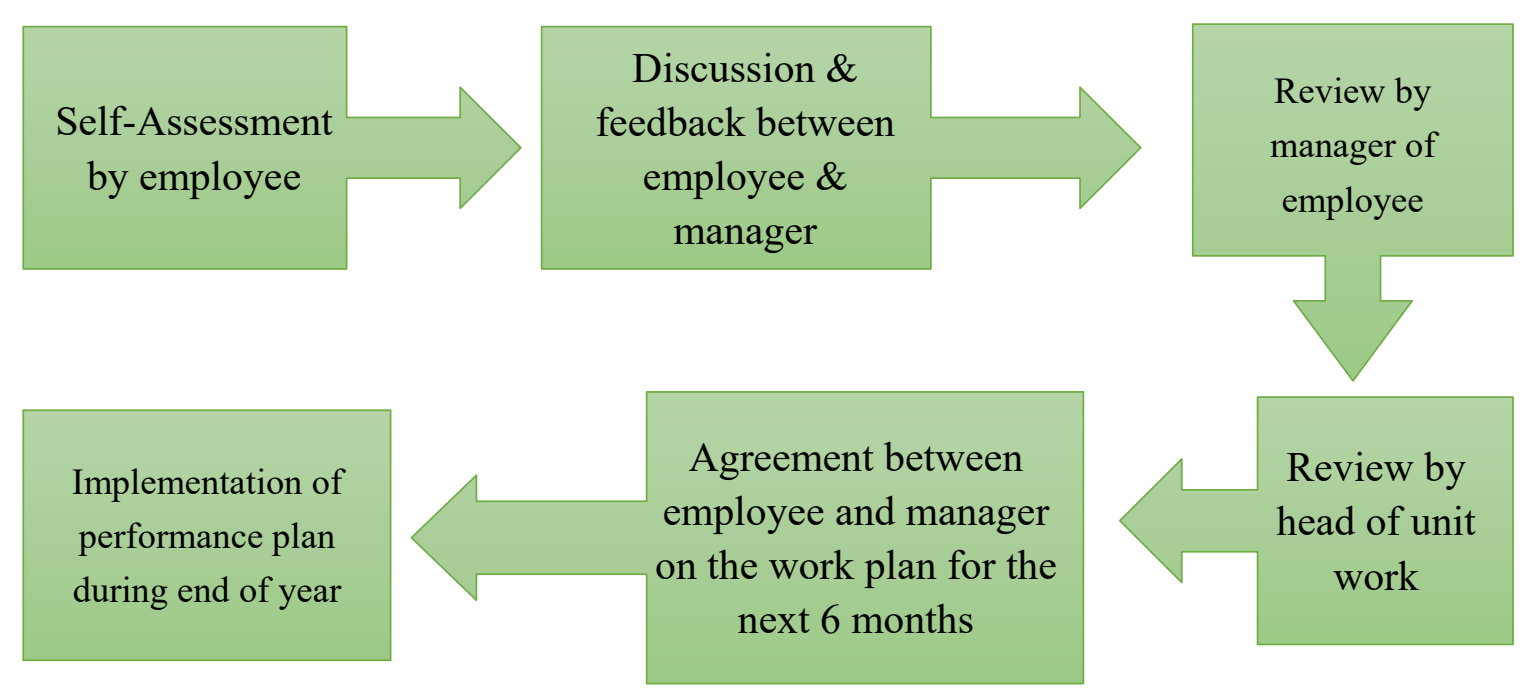

Figure 2. Flowchart Progress Review Performance

b. Year End Review

Performed at the end of the year, i.e. employee manager evaluates for a year against each KPI employees and assessment process that includes core and role competence. The final assessment is based on a thorough evaluation based on monitoring activities between superiors and employees. 

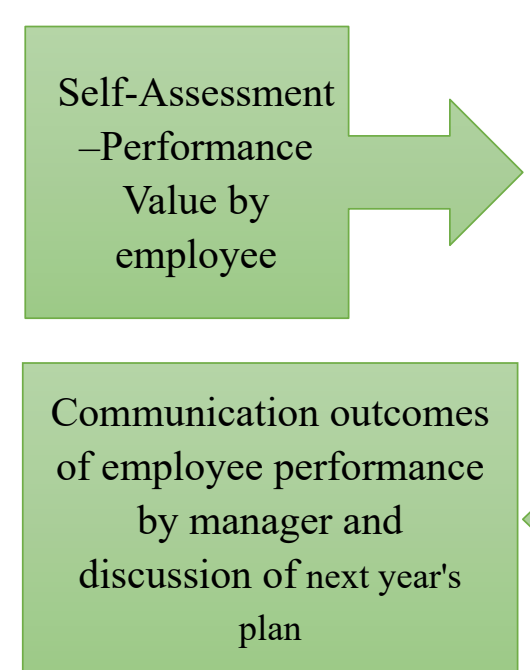
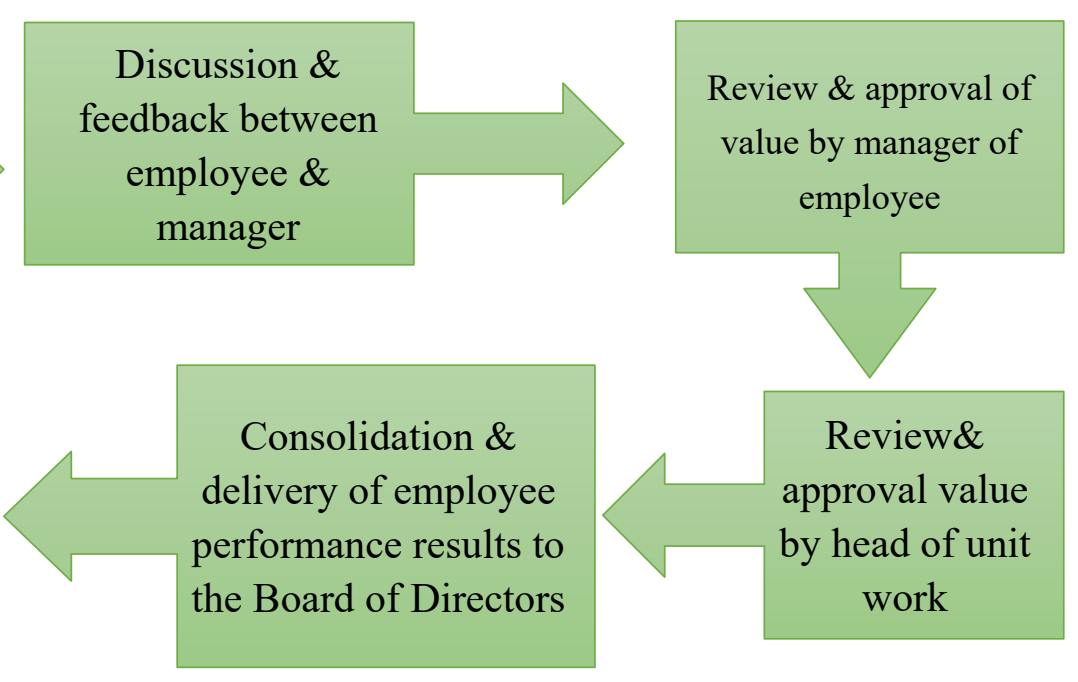

Review\& by head of unit work approval value

Figure 3. Flowchart Year End Review

4. Performance assessment consists of 2 (two) main components, namely:

a. Result: Shows what an employee has achieved ie with KPI / target (quantitative aspect)

b. Competence: How employees achieve these targets is with a competency profile (qualitative aspect).

5. The year end review uses the emphasis on the result / achievement of the KPI (quantitative aspect), so that $100 \%$ of the weight used is from the achievement of the employee KPI.

Table 2. Assessment Components

\begin{tabular}{|l|l|l|c|c|}
\hline \multicolumn{2}{|c|}{ Assessment Components } & \multicolumn{1}{|c|}{ Assessment Goals } & Value & Evaluation Period \\
\hline Result & $\begin{array}{l}\text { Based on work } \\
\text { goals }\end{array}$ & $\begin{array}{l}\text { To assess the level of } \\
\text { employee contribution to } \\
\text { business results }\end{array}$ & $100 \%$ & Quarterly \\
\hline Competency & $\begin{array}{l}\text { Based on the } \\
\text { Competency } \\
\text { profile }\end{array}$ & $\begin{array}{l}\text { To determine skill level and } \\
\text { development }\end{array}$ & $0 \%$ & Annual \\
\hline
\end{tabular}

6. For process components although not weighted (weight zero) quantitatively, but will be the basis of consideration in the career development of employees.

7. The scale and predicate employee performance appraisal is organized as follows: 
Table 3. Scale and Predicate of Assessment

\begin{tabular}{|l|c|c|c|c|c|c|}
\hline Score & $0-<75$ & $76-<85$ & $85-<94$ & $94-<102$ & $102-<109$ & $>109$ \\
\hline Condition & $\begin{array}{c}\text { Not } \\
\text { achieved }\end{array}$ & $\begin{array}{c}\text { Nearly } \\
\text { Achieved }\end{array}$ & $\begin{array}{c}\text { Achieved } \\
(-)\end{array}$ & $\begin{array}{c}\text { Achieved } \\
(+)\end{array}$ & $\begin{array}{c}\text { More } \\
\text { Achievable }\end{array}$ & $\begin{array}{c}\text { Very } \\
\text { achieved }\end{array}$ \\
\hline Predicate & Not Good & $\begin{array}{c}\text { Nearly } \\
\text { Good }\end{array}$ & Good (-) & Good (+) & Better & $\begin{array}{c}\text { Very } \\
\text { Good }\end{array}$ \\
\hline
\end{tabular}

8. Other provisions in the implementation of Performance Assessment

a. Change of work plan

1) Changes to the work plan of individual employees who have been agreed shall be made if there has been a change of KPI Unit of Work, in this case because of the significant uncontrollable factors that affect the achievement of Work Unit Tasks are:

a. Internal factors, originating from internal / internal Banks, for example: changes in Operational Policy and Organizational Structure changes.

b. External factors, which come from outside / external / outside the control of the Bank, for example: macroeconomic conditions, Monetary Policy / Regulators and natural disasters.

2) Implementation of the amendment of the KPI of the employee which has been agreed upon during the mid-term review period (2nd Quarter).

3) The employee manager is responsible for coordinating the appraisal of employees who have changed work plans and compiled into final assessments.

b. Mutation / Rotation

1) Every employee who occupies the position for at least 2 (two) months, must have KPI on the position and supervisor must give assessment, because it will affect the total value of employee performance for 1 (one) year.

2) Work Unit of Origin or Work Unit of destination where employee mutation / rotation shall discuss to consider continuity of achievement of job target of that position as a consequence of mutation / rotation.

c. Ad Hoc assignment

1) What is included as an ad hoc job is:

a. Jobs that are outside of the jobdesk and / or work plan.

b. Jobs are temporary and / or double positions.

c. Involvement in projects that are not the main KPI of the work unit.

2) Period of implementation of work in ad hoc minimum 1 (one) month or 22 working days. 
3) The total weight of the ad hoc assessment is set at a maximum of 5\% beyond the total final value. Each ad hoc assignment has a maximum weight of $2 \%$.

d. New employee

A new employee entitled to be evaluated / assessed is having a working period of at least 3 (three) months from the date of entry of the employee concerned.

e. Non-Active Employee

Personnel who have terminated their duties due to death or retirement, will continue to be assessed as long as the employee undergoes a period of at least 3 (three) months during the performance appraisal period of the year.

f. Employees Affected by Sanctions

To avoid the repercussions of double punishment of a single act, the coaching sanction given to employees does not affect the Performance Value of the employee concerned.

g. Participants of the Officer Development Program (ODP)

ODP participants participate in structured development programs where the expected achievements are tailored to each of the materials contained in the program. To that end, ODP participants have separate assessment mechanisms separate from employee performance appraisals.

\section{h. Special Offices}

Personnel with special positions (eg Project Manager, Professional Staff, Advisor, EBO, ERO, SKAP, DCOR, Decision Support) performance planning, progress reviews, and performance assessments are the authority of the respective Work Unit of the Trustees.

\subsubsection{Grouping of Performance Values}

1. The grouping of performance values aims to obtain a balance between the achievement of employees with the achievement of work units and the organization as a whole.

2. Grouping performance of employees through Performance Level (PL) is used as a basis in giving rewards / appreciation from the company to employees.

3. In the determination of the PL, the initial parameter used is the predicate of work unit performance divided into three levels namely:
a. Below Target
b. Meet Target
c. Exceed Target

The above performance predicate is performed by the Work Unit Strategy and Performance Management. Especially for Region Office along with the Unit of Work under it giving performance predicate is the result of study between Work Unit Strategy and Performance 
Management and Unit Work Distribution Strategy.

4. Employee PL determination is aligned with the level of attainment of the Work Unit and the composition should approach the normal distribution curve form using the PL 1 scale predicate to 6 .

5. The PL 1 is the employee with the top group of rankings while the PL 6 is the lowest ranked group of employees.

6. Determination of the composition / proportion of the number of employees who enter into a particular PL will refer to the predicate of work unit and BSM performance as a whole. This PL Matrix will be decided by management. Examples of OT matrices are as follows:

Table 4. Performance Level (PL)

\begin{tabular}{|c|c|c|c|c|c|c|c|}
\hline \multirow{2}{*}{$\begin{array}{c}\text { Predicate } \\
\text { Of Work Unit }\end{array}$} & \multicolumn{5}{|c|}{ PERFORMANCE LEVEL (PL) } & \multirow{2}{*}{ Total } \\
\cline { 2 - 7 } & PL 6 & PL 5 & PL 4 & PL 3 & PL 2 & PL 1 & \\
\hline Below & $5 \%$ & $15 \%$ & $35 \%$ & $30 \%$ & $10 \%$ & $5 \%$ & $100 \%$ \\
\hline Meet & $3 \%$ & $12 \%$ & $40 \%$ & $25 \%$ & $10 \%$ & $10 \%$ & $100 \%$ \\
\hline Exceed & $0 \%$ & $10 \%$ & $30 \%$ & $30 \%$ & $20 \%$ & $10 \%$ & $100 \%$ \\
\hline
\end{tabular}

7. The process of determining the OT employee is as follows:

a. Work Unit Strategy and Performance Management and Work Unit Distribution Strategy inform the Human Capital Work Unit regarding the predicate of each Work Unit to be recorded into the HR system.

b. Each Head of the Work Unit accesses the HR system to know the performance predicates of the Work Unit under which it manages, the composition, and the initial ranking of the OT employee below it.

c. Head of Work Unit has authority to recommend PL employee based on discussion and agreement from each direct supervisor / Manager of employee.

d. The final results of the personnel PL will be compiled by the Human Capital Work Unit to be decided in the Board of Directors Meeting.

e. The Head of the Work Unit is responsible for communicating the final OT results of the employee concerned and providing general feedback and evaluation of the final outcome.

\subsection{Performance Improvement Plan}

1. Performance Improvement Plan (PIP) is a performance improvement program for employees who have B (-), HB and TB performance assessments for 2 (two) consecutive years.

2. In this case the bank will implement a certain program to improve the performance of employees by providing a series of activities / action plan to improve employee performance within a certain time. 


\section{Macrothink}

Journal of Management Research

ISSN 1941-899X

2017, Vol. 9, No. 4

3. PIP design is undertaken by employee Manager, employee direct supervisor, Human Capital Work Unit of Human Capital Business Partner (HCBP) function, and the employee concerned and approved by the Head of Work Unit.

4. The program is implemented for 6 (six) months, and the program will be evaluated no later than 5 (five) working days after the end of the program period.

5. Monitoring the implementation of PIP is the responsibility of the Employee Manager and facilitated by the HCBP Human Capital Work Unit.

6. If based on the evaluation on the PIP program there is an increase in employee performance, then the company declares that the employee is entitled to continue working. However, if after following the PIP the employee is unable to improve its performance, then the company will re-enter in the 2nd PIP program (last program) for 6 (six) months ahead.

7. If based on the evaluation of the 2nd PIP program there is an increase in performance, then the employee is entitled to continue working. However, if after following the 2nd PIP program is still not able to improve its performance, then the employee agrees to resign in accordance with applicable provisions.

8. If after attending the PIP program (either 1 or 2 ), the employee will again get the predicate $\mathrm{B}(-), \mathrm{HB}$ and $\mathrm{TB}$ for the performance appraisal period of the year, then the employee agrees to resign in accordance with the applicable provisions.

\section{Discussion}

\subsection{Stages of Performance Management at BSM}

Application of performance management in BSM from performance management cycles, performance planning, performance appraisal, performance value plan classification and performance improvement plan. In this discussion we will try to enter the stage of performance management according to William (1998) which consists of 4 stages:

1. First Stage: Directing/planning

BSM has conducted a process of identifying work behavior by means of communication between employees and superiors in order to achieve common understanding of goals, methods and methods of measuring the achievement of targets.

Planning or performance planning at BSM consists of 5 parts:

a. Performance planning system is integrative of corporations, directorates, work units and individuals with the following stages:

1) The Bank shall prepare the targets of work set forth in the Bank's Business Plan

2) The Directorate develops a target before establishing the Balance Scorecard (BSC) of each work unit.

3) The work unit establishes the target of each in the form of balance scorecard/KPI 
4) The work unit set the job target for each employee refers to the BSC (KPI) and job description (job description)

b. Process of cascading (KPI) by the work unit to employees under its coordination. KPI must be in line with the target work unit and divided according to potential/employee capabilities.

c. Performance indicators in BSM must meet the SMART criteria.

d. Each work target has a weight set jointly between superiors and subordinates in accordance with work priority with total weight equal to $100 \%$.

e. Each work objective must be accompanied by a Key Performance Indicator tailored to the specified work objectives.

2. The second stage: managing/supporting. The second stage is the implementation of monitoring on organizational processes. This stage focuses on manage, support, and control over the course of the process to stay on track. At this stage BSM conducts monitoring, support and control by heads of work units and supervisors. Head of Work Unit and supervisors are responsible for providing direct guidance and motivation in the form of coaching, counseling and feed back to subordinates in order to work better and avoid failure of achievement of targets at the end of the year.

3. Third stage: review/appraising. Assessment of the achievement of the work done by comparing the target with the realization of the achievement of targets. The processes undertaken in the performance appraisal are as follows:

a) Progress review (explanation is in chapter 3)

b) Year end review (explanation is in chapter 3)

Performance assessment consists of 2 (two) main components, namely:

a) Result: Shows what an employee has achieved ie with KPI/target (quantitative aspect)

b) Competence: How employees achieve these targets are with a competency profile (qualitative aspect).

Form of assessment of the KPI is concluded in the form of scale and predicate employee performance appraisal.

4. The fourth stage: developing/rewarding. Evaluation results become the decision-making guideline for the next action. Assessment is very decisive in grade increase and reward/reward to employees.

The grouping of employee performance through performance level (PL) is used as the basis for reward/appreciation from company to employee. Employee PL determination is aligned with the achievement level of the Work Unit and the composition should approach the normal distribution curve form using the PL 1 scale predicate to 6 . The process of determining the PL employee is as follows: 
a) the Strategy and Performance Management Work Unit and the Distribution Strategy Work Unit inform the Human Capital Work Unit regarding the predicate of each Work Unit to be recorded into the HR system.

b) Each Head of the Work Unit accesses the HR system to know the performance predicates of the Work Unit under which it manages, the composition, and the initial rank of the PL employee below it.

c) Head of Work Unit has authority to recommend PL employee based on discussion and agreement from each direct supervisor/Manager of employee.

d) The employee's final outcome will be compiled by the Human Capital Work Unit to be decided in the Board of Directors' Meeting.

e) The Head of the Work Unit is responsible for communicating the final PL results of the employee concerned and providing general feedback and evaluation of the outcome.

For employees or workers whose performance has not been satisfactory or has not been achieved BSM has a program that is Performance Improvement Plan is a performance improvement program for employees who have performance assessment B (-), HB and TB for 2 (two) consecutive years. By providing a series of activities / action plan to improve employee performance within a certain time.

Based on the four stages of performance management according to William above that PT. Bank Syariah Mendiri has implemented performance management as it should. So that BSM can organize the organization more structured, organizational performance becomes effective and efficient and also encourage employees to work according to procedures, spirit and productive.

\subsection{Advantages of Performance Management Implementation}

Here are the advantages of performance management implementation in Bank Syariah Mandiri:

1. Clear goals for the organization and the correct process for identifying, developing, measuring, and discussing objectives.

2. Integration between objectives broadly made by the company with the goals of each worker.

3. Better clarity about the aspirations and goals of the organization.

4. There is continuous dialogue between management and workers.

5. Development of a more open environment.

6. The company can achieve the desired results according to its vision and mission.

7. Encourage personal or employee development to work more effectively and efficiently and make a positive contribution to the company. 


\subsection{Disadvantages of Performance Management Implementation}

The following lacks in the implementation of performance management at BSM:

1. Regarding the assessment, sometimes employees who get an assessment can not get a further explanation of what is behind the assessment.

2. Sometimes in the case of assessments made by less experienced and poorly trained assessors, the accuracy of the results of these assessments is likely to be dubious. What happens then is the inflation of values in which everyone's performance looks good or otherwise deflationary.

3. BSM still uses Balanced Scorecard method (BSC) as a means of measuring workers so that there are some weaknesses in BSC implementation that BSC has not been able to precisely determine the compensation system which is usually a follow-up of performance results.

\section{Conclusion}

Performance management is applied to achieve the company's vision and mission through employee competence and performance that match the values contained within the company. The targets of each work unit based on the balance scorecard set by the Directorate. BSM employee performance is monitored through key performance indicator. Head of work units and supervisors are responsible for providing direct guidance and motivation in the form of coaching, counseling and feed back to subordinates in order to work better and avoid failure to achieve targets at the end of the year. Performance appraisal of BSM employees is done periodically every 3 months, i.e. quarterly review and annual review. The grouping of employee performance through Performance Level (PL) is used as the basis for reward / appreciation from company to employee. Employee PL determination is aligned with the level of achievement of the Work Unit and the composition should approach the shape of a normal distribution curve using a PL predicate of 1 to 6 scale. Persons conducting performance appraisal are themselves through self-assessment and direct superior through interviews based on evidence of activity employee performance (self-assessment result). Feedback from the annual review process is in the form of HR related policies and reviews for corporate strategy in the next period. Implementation of performance management in BSM is good enough so that the company performance more structured and organized, effective and efficient and encourage employees to work according to procedures, spirit and productive so that the work is more optimal and contribute positively to the company

\section{Suggestion}

The advice of the author for the implementation of performance management in BSM are:

1. In order for BSM to review the use of performance level (PL) as the basis of reward/appreciation from the company to employees due to the potential of injustice (like or dislike) in the performance level of employees. 


\section{Macrothink}

Journal of Management Research

ISSN 1941-899X

2017, Vol. 9, No. 4

2. In order for BSM to re-socialize the current performance management system so that employees better understand the purpose and objective of the implementation of performance management system used by BSM

\section{References}

AA. Anwar Prabu Mangkunegara, (2000). Manajemen Sumber Daya Manusia Perusahaan. Bandung: PT Remaja Rosdakarya.

Aguinis, Herman. (2009). Performance management (2nd). Pearson Education, Inc., Upper Saddle River, New jersey

Ambarwati, Sri Dwi Ari. (2002). Managing Productive Performance Appraisal: Sebuah Upaya Menjawab Kebutuhan Penilaian Kinerja Karyawan Bebas KKN. Jurnal Siasat Bisnis. Vol.7 No.1:93-111.Yogyakarta.

Amstrong \& Baron. (1998). Perfect Management. London: Institute of Personal and Development

Dessler G, Tan Chwee Huat. (2009). Human Resource Management: An Asian. Perspective. Singapore: Prentice Hall Pearson Education South Asia Pte.

Esu, Bassey B. \& Benjamin J. Inyang. (2009). A Case for Performance Management in the Public Sector in Nigeria. International Journal of Business and Management. Vol 4. No. 4: 98-105. Calabar.

Hasibuan, Malayu. (2001). Manajemen Sumber Daya Manusia: Pengertian Dasar, Pengertian, dan Masalah. Jakarta: PT. Toko Gunung Agung.

Mathis, Robert L, John H. Jackson, (2006). Manajemen Sumber Daya Manusia. 10th Ed., Salemba Empat. Jakarta. Massachusetts: Prentice-Hall.

Marwansyah, (2010). Manajemen Sumber Daya Manusia. Edisi Kedua, Alfabeta. Bandung.

Mondy, R. W., \& Noe, R. M. (2005). Human Resource Management. 9th Ed.

Rivai, Veittzel. (2006). Manajemen Sumber Daya Manusia untuk Perusahaan. Raja Grafindo Persada, Jakarta

Wibowo, (2016). Manajemen Kinerja. Edisi kelima, PT Raja Grafindo Persada, Jakarta.

Wirawan, (2009). Evaluasi Kinerja: Teori, Aplikasi, dan Penelitian. Salemba Empat, Jakarta.

Williams, R.S. (1998). Performance Management: Perspectives on Employee Performance. International Thomson Business Press, London. 